\title{
Soil classification at Muaro Baru beach of Padang City using CPT data
}

\author{
Rina Yuliet $^{1 *}$, Mas Mera ${ }^{1}$, and Krismon Hidayat $^{1}$ \\ ${ }^{1}$ Department of Civil Engineering, Engineering Faculty, Andalas University, Indonesia
}

\begin{abstract}
Many semi-empiric correlations have been developed to estimate geotechnical parameters based on Cone Penetration Test (CPT) data for various types of soils. This paper aims to classify soil types based on CPT data with several semi-empiric correlations and compare the results of some of these correlations. In this study, the field CPT and the laboratory test were carried out on soil from two closely spaced locations in the estuary area of Muaro Baru, Padang city. The CPT data was used to determine the soil type using several semi-empirical correlations, namely; friction ratios, Schertmann (1978), Robertson and Campanella (1983), and Robertson et al. (1986), then updated by Robertson in 2010. Soil Behaviour Type (SBT) is based on the cone resistance $\left(\mathrm{q}_{\mathrm{c}}\right)$, sleeve friction $\left(\mathrm{q}_{\mathrm{s}}\right)$, and friction ratio $\left(\mathrm{R}_{\mathrm{f}}\right)$. The Unified Soil Classification System (USCS) is also used to classify soils using sieve analysis. The results showed that from the several semi-empirical correlations obtained compatibility soil classification and soil profiles.
\end{abstract}

\section{Introduction}

The soil properties are very dependent on the size of the grain, so grain size is used as a basis for naming and classifying the soil-however, most types of soil consist of a mixture of particle sizes. Sand is described as noncohesive and non-plastic soil. The soil properties are very dependent on the grain size, which is used as a basis for naming and classifying the soil. Investigation of soil properties is beneficial when evaluating building settlement risks, determining the flow rate of water passing through a soil structure, and evaluating the shear strength of a soil that allows the stability of a slope to be calculated.

Most soil classifications are very simple based on a sieving analysis and an Atterbergh limits test in the laboratory. Standard soil classification systems are the USCS and the AASHTO. These systems use soil properties such as grain size distribution, liquid limit, and plasticity index. Soil classification can also be done using a Cone Penetration Test (CPT). The CPT is one of the most common in-situ tests used to evaluate soil types. Much research has been done to identify and classify soils from CPT data $[1,2,3]$.

Mohamed (2003) reports that no theoretical procedure can predict the actual soil type of a location. Cone resistance $\left(\mathrm{q}_{\mathrm{c}}\right)$ and sleeve resistance $\left(\mathrm{f}_{\mathrm{s}}\right)$ provide insufficient information to classify soil type. Factors such as the history of stress, water content, density, local inclusions of material such as gravel and lenses also affect the final value of $q_{c}$ and $f_{s}$. At the same time, the method developed by previous researchers was only suitable for the area where the method was developed. Furthermore, a CPT test should also be supplemented with information from direct drilling. [3]. ${ }^{\mathrm{b}}$

Previous researchers have developed empirical equations to classify soil based on CPT data. However, this research has focused chiefly on sub-tropical and regions. Research on this subject for tropical regions like Indonesia is very limited [4]. These empirical equations are based on CPT data are inconsistent with laboratory tests [5].

The soil in the Nurul Haq Shelter area, $37 \mathrm{~m}$ from the coast of Padang city, West Sumatera, is known from previous Standard Penetration Test (SPT) data to be silty sand to a depth of $6 \mathrm{~m} \mathrm{[6-8].} \mathrm{In} \mathrm{the} \mathrm{present} \mathrm{research,} \mathrm{this}$ soil was field-tested with CPT and a sieve analysis in the laboratory to determine the type of soil behavior and classify it according to the USCS system. The soil investigation is the coastal area of Muaro Baru close to the river mouth. The CPT test was carried out at 2 points $10 \mathrm{~m}$ apart, and the sieve analysis was carried out on shallow soil $(0-60 \mathrm{~cm})$.

\subsection{Soil Behaviour Type (SBT) on CPT data}

CPT can be used on all soil types, from soft soils and very stiff clay soils. It provides a quick soil profile, is economical, and provides repeatable data, and there is a solid theoretical basis for interpreting the results. The difference in friction ratio between side resistance and cone resistance is needed to interpret CPT data. The relative size of these variables depends on soil type. The cone resistance $\left(\mathrm{q}_{\mathrm{c}}\right)$ in the sand is higher than in clay, and

\footnotetext{
*Corresponding author: rina@eng.unand.ac.id
} 
the friction ratio $\left(\mathrm{R}_{\mathrm{f}}\right)$ in the sand is lower than in clay. CPT cannot determine soil grain size but can determine soil mechanical characteristics (strength, stiffness, compressibility) and SBT.

Many semi empiric correlations have been developed to estimate geotechnical parameters based on CPT data for various soils. The first CPT was made in 1932. After that, in 1953, soil classification based on CPT was first created by Begemann (Fig. 1) [9].

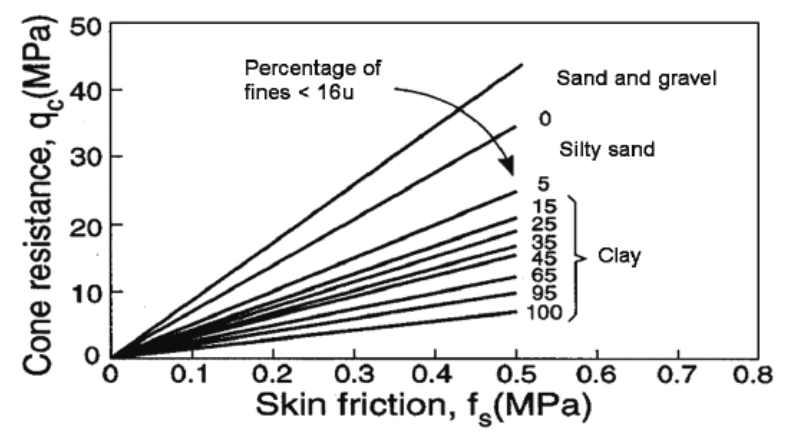

Fig. 1. Soil type based on Begemann (1953) method [9]

Another method for interpreting CPT data is the initial assessment using the friction ratio $\left(\mathrm{R}_{\mathrm{f}}\right)$ shown in Table 1 .

Table 1. Soil type based on friction ratios [10]

\begin{tabular}{|c|l|}
\hline Friction Ratio, $\mathbf{R}_{\mathbf{f}}(\mathbf{\%})$ & \multicolumn{1}{c|}{ Soil Type } \\
\hline$<1$ & Coarse to medium sand \\
\hline $1-2$ & Fine sand, silty to clayey sands \\
\hline $2-5$ & $\begin{array}{l}\text { Sandy clay, silty clays, clays, } \\
\text { organic clays }\end{array}$ \\
\hline$>5$ & Peat \\
\hline
\end{tabular}

Variation between friction ratio and cone resistance is also needed in the final analysis. This correlation varies, and each has reliability in its application. Soil classification is based on a combination of both friction ratio and cone resistance according to Schertmann (1978), Robertson and Campanella (1983) are shown in Fig. 2 and Fig. 3, respectively.

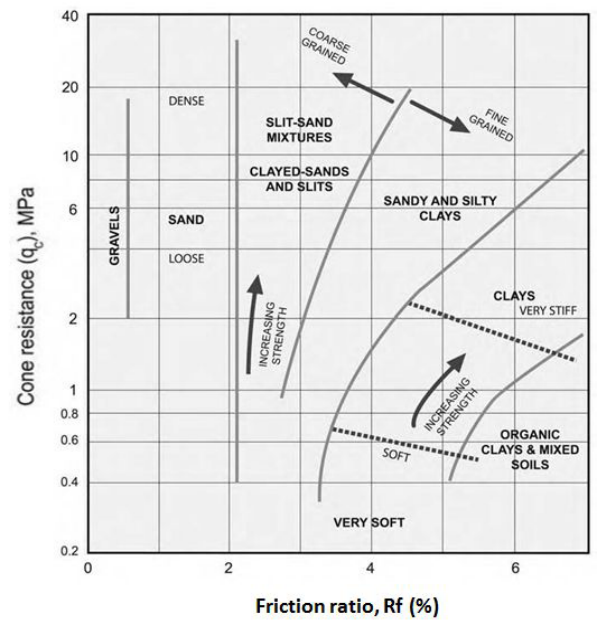

Fig. 2. Soil type based on Schertmann (1978) [10]

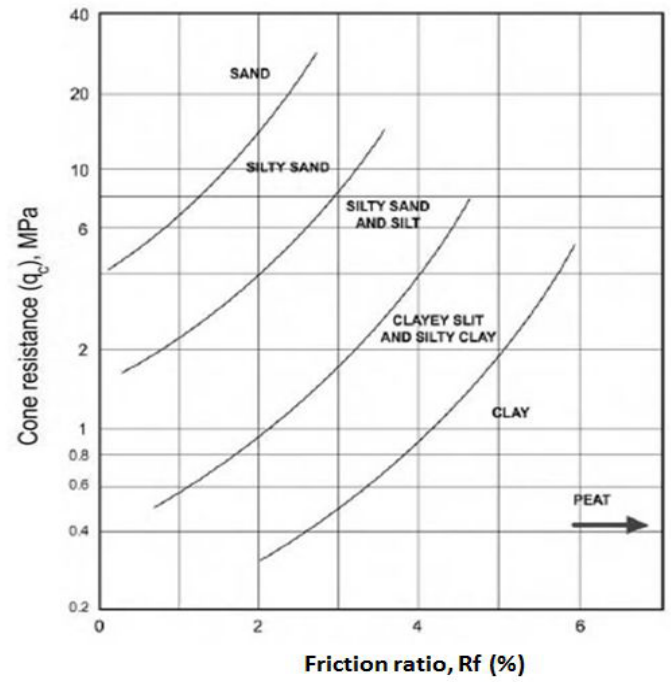

Fig. 3. Soil type based on Robertson and Campanella (1983) method [10]

Usually, based on CPT data, the cone resistance $\left(\mathrm{q}_{\mathrm{c}}\right)$ in the sand is higher than in clay, and the sand's friction ratio $\left(\mathrm{R}_{\mathrm{f}}=\mathrm{f}_{\mathrm{s}} / \mathrm{q}_{\mathrm{c}}\right)$ is lower than in clay. CPT cannot determine soil physical characteristics such as grain size but can determine soil mechanical characteristics (strength, stiffness, compressibility) and Soil Behaviour Type (SBT). The most common SBT chart using CPT data is suggested by Robertson et al. (1986) then updated by Robertson in 2010 in the dimensionless version (Fig. 4).

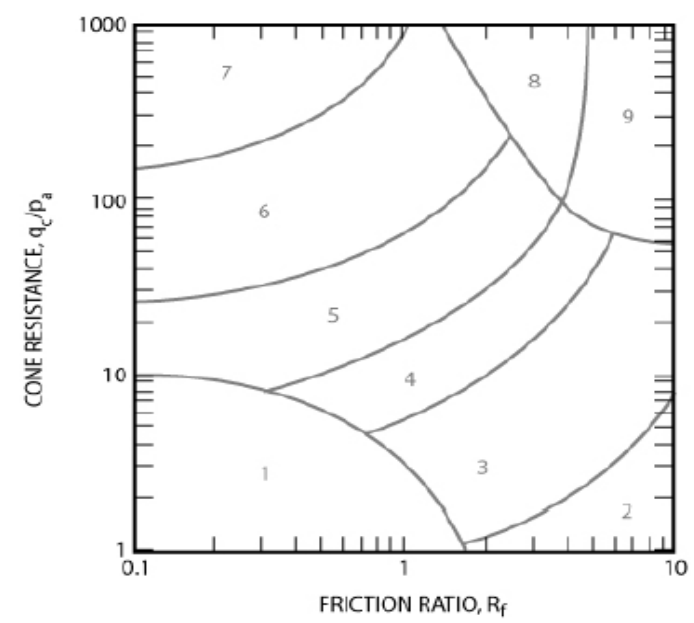

Fig. 4. Soil type based on Robertson et al. (1986) updated by Robertson (2010) [9]

Table 2. Soil Behaviour Type (SBT) [9]

\begin{tabular}{|c|c|}
\hline Zone & Soil Behavior Type \\
\hline 1 & Sensitive, fine grained \\
2 & Organic soils - clay \\
3 & Clay - silty clay to clay \\
4 & Silt mixtures - clayey silt to silty clay \\
5 & Sand mixtures - silty sand to sandy silt \\
6 & Sands - clean sand to silty sand \\
7 & Gravelly sand to dense sand \\
8 & Very stiff sand to clayey sand* \\
9 & Very stiff fine grained \\
\hline
\end{tabular}




\subsection{Soil classification based on USCS}

The physical properties of the soil are influenced by the distribution of soil grain size and the amount of each mineral component in the soil which determines the soil plasticity. There are two commonly accepted soil classification systems; the AASHTO and the USCS classification systems. Both systems take into account the grain size distribution and the Atterbergh limit. Road engineers use the AASHTO classification system more often, while geotechnical engineers commonly use the Unified Classification System (USCS).

\subsection{Clay strength from CPT}

Table 3 uses the above relationships to establish the clay's likely strength.

Table 3. Correlation of $\mathrm{q}_{\mathrm{c}}$ and $\mathrm{cu}[10]$

\begin{tabular}{|l|c|c|c|}
\hline Consistency & $\begin{array}{c}\text { Cohesion } \\
\text { Undraine } \\
\mathbf{d}, \mathbf{c}_{\mathbf{u}}(\mathbf{k P a})\end{array}$ & $\begin{array}{c}\mathbf{q} \mathbf{c} \\
(\mathbf{M P a})\end{array}$ & $\begin{array}{c}\text { Assumption. } \\
\text { Not corrected } \\
\text { for } \\
\text { overburden }\end{array}$ \\
\hline Very Soft & $0-12$ & $<0.2$ & $\mathrm{~N}_{\mathrm{k}}=17$ \\
\hline Soft & $12-25$ & $0.2-0.4$ & $\mathrm{~N}_{\mathrm{k}}=17$ \\
\hline Firm & $25-50$ & $0.4-0.9$ & $\mathrm{~N}_{\mathrm{k}}=18$ \\
\hline Stiff & $50-100$ & $0.9-2.0$ & $\mathrm{~N}_{\mathrm{k}}=18$ \\
\hline Very stiff & $100-200$ & $2.0-4.2$ & $\mathrm{~N}_{\mathrm{k}}=19$ \\
\hline Hard & $\geq 200$ & $>4.0$ & $\mathrm{~N}_{\mathrm{k}}=20$ \\
\hline
\end{tabular}

\subsection{Sand strength from CPT}

Meyerhoff (1956) presents the correlation of the $\mathrm{q}_{\mathrm{c}}$ value of the CPT test results and the relative density $\left(\mathrm{D}_{\mathrm{r}}\right)$ to the friction angle $(\phi)$ for sand (Table 4). Table 3 can be used to determine preliminary sand strength from CPT data [11].

Table 4. Correlation of $\mathrm{q}_{\mathrm{c}}, \mathrm{D}_{\mathrm{r}}$ and $\phi$ (Meyerhoff, 1956) [11]

\begin{tabular}{|c|c|c|c|}
\hline Consistency & $\begin{array}{c}\text { Relative } \\
\text { Density } \\
\text { (Dr) }\end{array}$ & $\begin{array}{c}\mathbf{q}_{\mathbf{c}} \\
(\mathbf{M P a})\end{array}$ & $\begin{array}{c}\text { Estimated } \\
\text { friction angle } \\
\text { value, } \phi\left({ }^{\circ}\right)\end{array}$ \\
\hline Very Loose & $<0.2$ & $<2$ & $<30$ \\
\hline Loose & $0.2-0.4$ & $2-4$ & $30-35$ \\
\hline Medium Loose & $0.4-0.6$ & $4-12$ & $35-40$ \\
\hline Dense & $0.6-0.8$ & $12-20$ & $40-45$ \\
\hline Very Dense & $>0.8$ & $>20$ & $>45$ \\
\hline
\end{tabular}

\section{Methodology}

In this study, the tests carried out were field tests (Cone Penetration Test/CPT, SNI 2827-2008) [12] and laboratory tests (grain size analysis test, SNI 3423-2008) [13]. Field testing and soil sampling were carried out at two adjacent points with a distance between the two points of $10 \mathrm{~m}$ in Muaro Baru Pasie Nan Tigo (Fig. 5). The two test points are coded, namely Muaro Baru 1 (MB1) and Muaro Baru 2 (MB2).

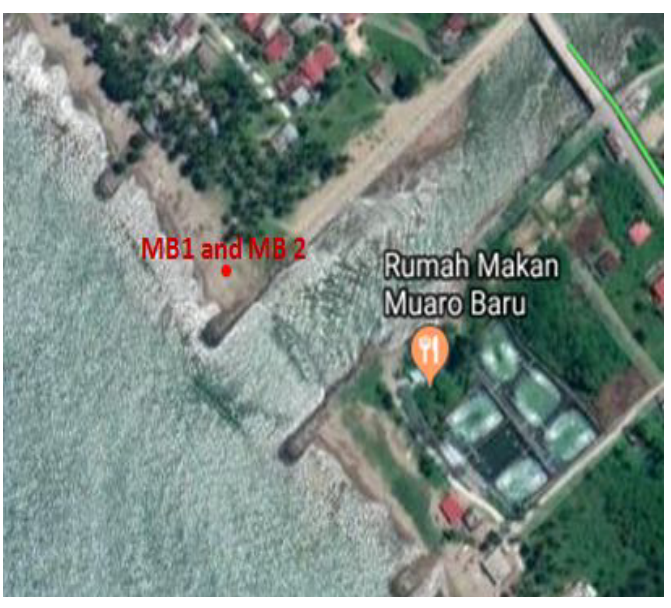

Fig. 5. Location map of research Muaro Baru beach of Padang City

To get the calculation parameters that are required, these two CPT data will then be plotted into the many semi empiric correlations to be used to estimate the soil type in the study area. The semi empiric correlations used to determine soil type are; friction ratios, Schertmann (1978), Robertson and Campanella (1983), and Robertson et al. (1986), updated by Robertson (2010). From CPT data, the cone resistance $\left(\mathrm{q}_{\mathrm{c}}\right)$ and sleeve friction $\left(\mathrm{f}_{\mathrm{s}}\right)$ values are obtained, then calculate the friction ratio $\left(\mathrm{R}_{\mathrm{f}}=\mathrm{f}_{\mathrm{s}} / \mathrm{q}_{\mathrm{c}}\right)$.

\section{Results and Analysis}

\subsection{Soil classification based on USCS}

Grain size distribution graphs for the Muaro Baru area (MB1 and MB2) can be seen in Fig. 7. At 0-60 cm depth, the soil type is around $98 \%$ sand and $2 \%$ silt soil.

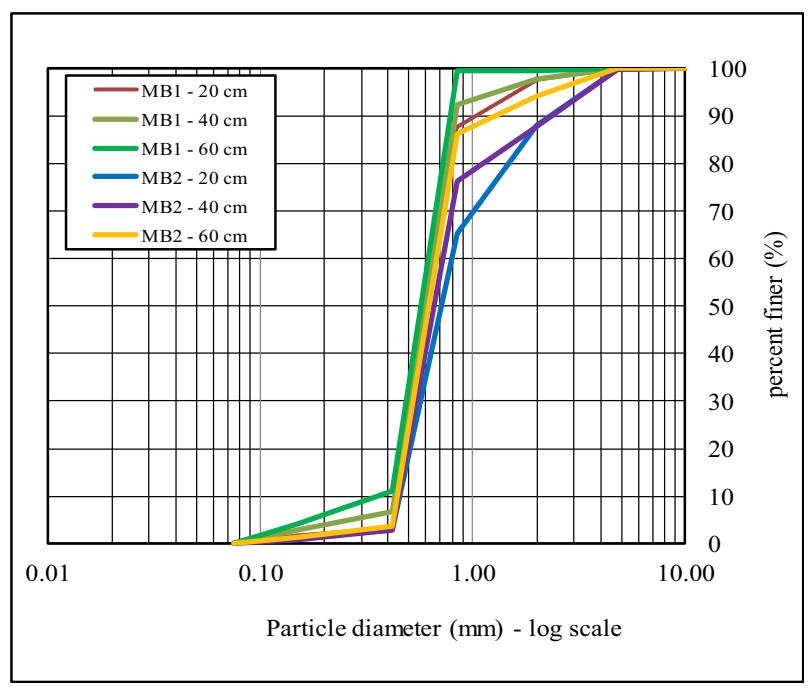

Fig. 7. Particle-size distribution of two locations

Based on Fig. 7, these soils be classified as Poorly graded Sand (SP). The results of soil classification based on USCS for MB1 and MB2 areas are shown in Table 4. 
Table 4. Soil classification by USCS

\begin{tabular}{|c|c|c|c|c|c|c|c|}
\hline Parameter & $\begin{array}{l}\text { MB1- } \\
20 \mathrm{~cm} \\
\end{array}$ & \begin{tabular}{|l|} 
MB1- \\
$40 \mathrm{~cm}$ \\
\end{tabular} & $\begin{array}{l}\text { MB1- } \\
60 \mathrm{~cm} \\
\end{array}$ & \begin{tabular}{|l|} 
MB2- \\
$20 \mathrm{~cm}$ \\
\end{tabular} & \begin{tabular}{|l|} 
MB2- \\
$40 \mathrm{~cm}$ \\
\end{tabular} & \begin{tabular}{|l|} 
MB2- \\
$60 \mathrm{~cm}$ \\
\end{tabular} & \begin{tabular}{|l|}
$M B 3-$ \\
$20 \mathrm{~cm}$ \\
\end{tabular} \\
\hline$\%$ Passing No. 200 sieve & 0 & 0 & 0 & 0 & 0 & 0 & 1.4 \\
\hline$\%$ Retained on No. 4 sieve & 0 & 0 & 0 & 0 & 0 & 0 & 0 \\
\hline $\mathrm{D} 10(\mathrm{~mm})$ & 0.45 & 0.43 & 0.36 & 0.45 & 0.45 & 0.45 & 0.16 \\
\hline D30 (mm) & 0.52 & 0.51 & 0.47 & 0.56 & 0.54 & 0.52 & 0.19 \\
\hline D60 (mm) & 0.67 & 0.65 & 0.62 & 0.8 & 0.72 & 0.67 & 0.27 \\
\hline $\mathrm{Cu}$ & 1.49 & 1.51 & 1.72 & 1.78 & 1.6 & 1.49 & 1.7 \\
\hline $\mathrm{Cc}$ & 0.9 & 0.93 & 0.99 & 0.87 & 0.9 & 0.9 & 0.84 \\
\hline Group symbol & SP & SP & $\mathrm{SP}$ & SP & SP & SP & SP \\
\hline Note $: \mathrm{SP}=$ Poorly Graded & & & & & & & \\
\hline
\end{tabular}

\subsection{Interpretation results from CPT data}

The results of the CPT data for the MB1 area can be seen in Fig. 8. The plotting data for the MB1 area can be seen in Fig. 9, Fig. 10, and Fig. 11, respectively. Recapitulation of the results of plotting data in the MB1 areas is shown in Table 5.
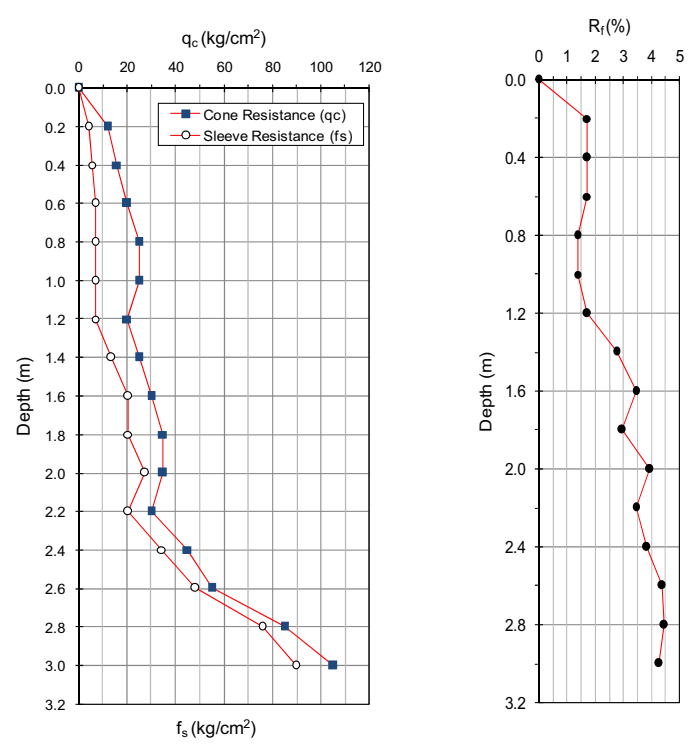

Fig. 8. CPT results for MB1

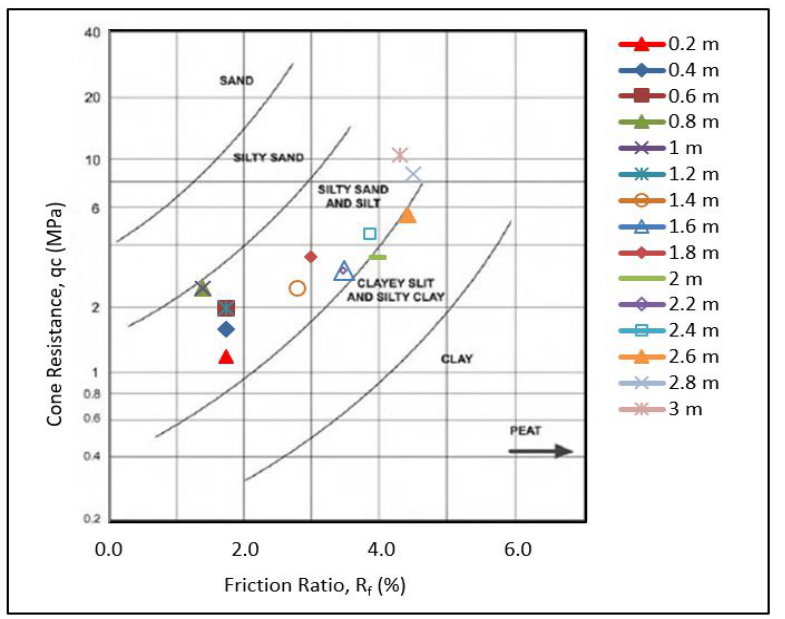

Fig. 9. Plotting CPT data for MB1(Robertson and Campanella, 1983)

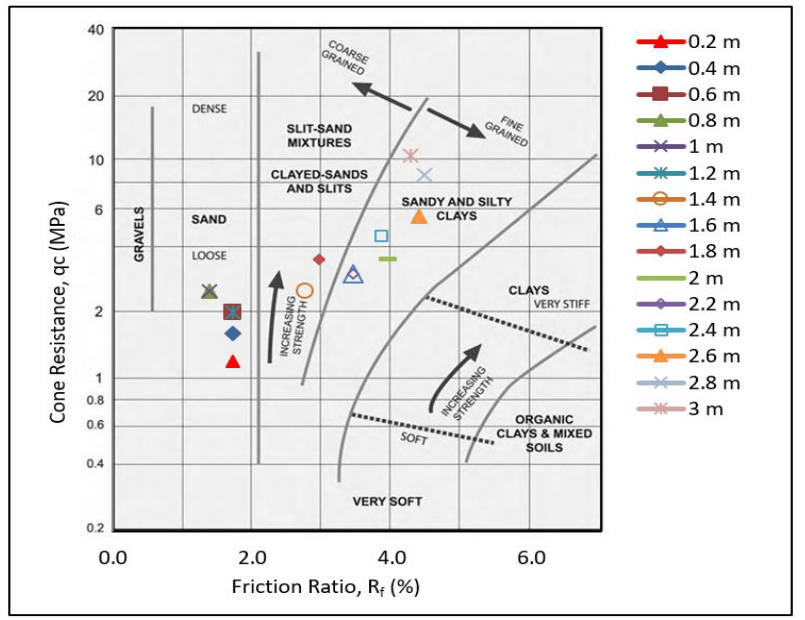

Fig. 10. Plotting CPT data for MB1 (Schertmann, 1978)

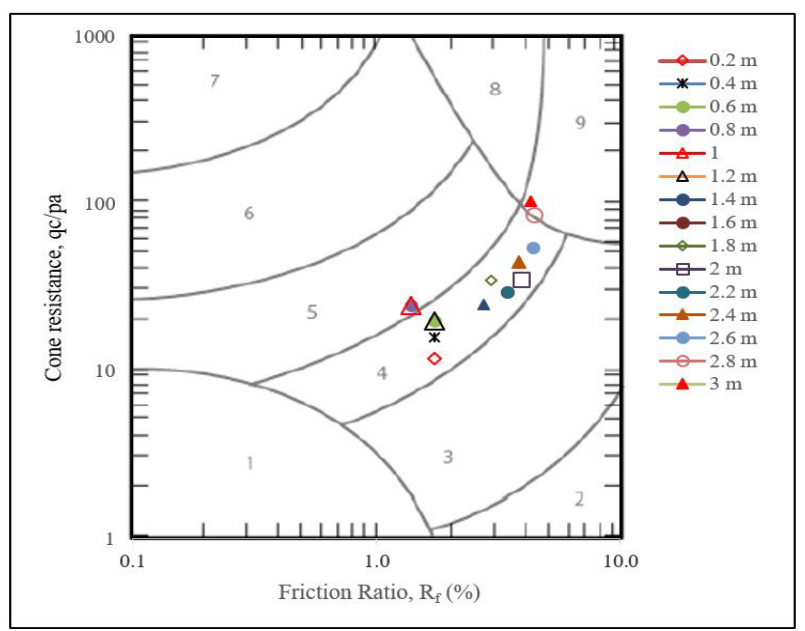

Fig. 11. Plotting CPT data for MB1 (Robertson et al., 1986, updated by Robertson, 2010)

From Table 5, it can be seen that the distribution of data for the semi-empirical correlation based on friction ratios at the MB1 areas obtained a soil profile consisting of two layers of soil. In the first layer, the soil type is fine sand, silty to clayey sands. In the second layer, the soil types are sandy clay, silty clays, clays, organic clays.

According to Robertson and Campanella (1983), the soil profile at the MB1 consists of five soil layers. The first, third, and fifth layers have the same soil type: silty sand and silt, while the second and fourth layers have soil types clayey silt and silty clay.

According to Schertmann (1978), the soil profile to MB1 areas consists of five soil layers; The first layer is loose sand; the second and fourth layers are clayed-sands and silts, the third and fifth layers are sandy and silty clay.

Robertson et al. (1986), updated by Robertson (2010), obtained four soil layers in the MB1 areas. The first and third layers are silty-mixtures clayey silt to silt clay, the second layer sandy-mixtures silty sand to sandy silt, the fourth layer is very stiff fine-grained. 
Table 5. Soil Behaviour Type (SBT) MB1 area

\begin{tabular}{|c|c|c|c|c|}
\hline $\begin{array}{l}\text { Depth } \\
\text { (m) }\end{array}$ & $\begin{array}{l}\text { Friction } \\
\text { ratios }\end{array}$ & $\begin{array}{l}\text { Robertson and } \\
\text { Campanella } \\
\text { (1983) }\end{array}$ & $\begin{array}{c}\text { Schertmann } \\
(1978)\end{array}$ & $\begin{array}{l}\text { Robertson et al., } \\
\text { 1986, updated by } \\
\text { Robertson, } 2010\end{array}$ \\
\hline 0 & \multirow{7}{*}{$\begin{array}{c}\text { Fine sand, } \\
\text { silty to } \\
\text { clayey } \\
\text { sands }\end{array}$} & \multirow{10}{*}{ Silty Sand and Silt } & \multirow{7}{*}{ Loose Sand } & \multirow{4}{*}{$\begin{array}{l}\text { silt mixtures-clayey } \\
\text { silt to silt clay }\end{array}$} \\
\hline 0.2 & & & & \\
\hline 0.4 & & & & \\
\hline 0.6 & & & & \\
\hline 0.8 & & & & \multirow{2}{*}{$\begin{array}{l}\text { sand mixtures-silty } \\
\text { sand to sandy silt }\end{array}$} \\
\hline 1 & & & & \\
\hline 1.2 & & & & \multirow{9}{*}{$\begin{array}{l}\text { silt mixtures-clayey } \\
\text { silt to silt clay }\end{array}$} \\
\hline 1.4 & \multirow{9}{*}{$\begin{array}{c}\text { sandy clay, } \\
\text { silty clays, } \\
\text { clays, } \\
\text { organic } \\
\text { clays }\end{array}$} & & $\begin{array}{l}\text { Clayed-sands } \\
\text { and silts }\end{array}$ & \\
\hline 1.6 & & & $\begin{array}{l}\text { Sandy and } \\
\text { silty clays }\end{array}$ & \\
\hline 1.8 & & & $\begin{array}{l}\text { Clayed-sands } \\
\text { and silts }\end{array}$ & \\
\hline 2 & & $\begin{array}{l}\text { clayey silt and silty } \\
\text { clay }\end{array}$ & \multirow{6}{*}{$\begin{array}{l}\text { Sandy and } \\
\text { silty clays }\end{array}$} & \\
\hline 2.2 & & Silty Sand and Silt & & \\
\hline 2.4 & & & & \\
\hline 2.6 & & $\begin{array}{l}\text { clayey silt and silty } \\
\text { clay }\end{array}$ & & \\
\hline 2.8 & & \multirow[b]{2}{*}{ Silty Sand and Silt } & & \\
\hline 3 & & & & $\begin{array}{l}\text { verry stiff fine } \\
\text { grained }\end{array}$ \\
\hline
\end{tabular}

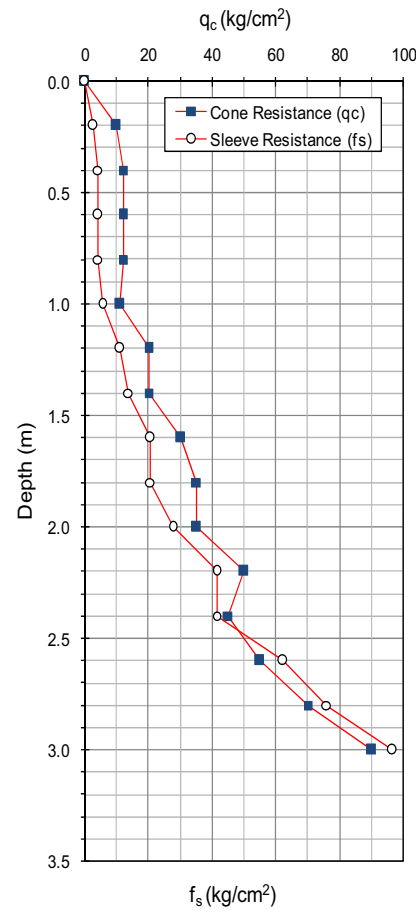

$\mathrm{R}_{\mathrm{f}}(\%)$

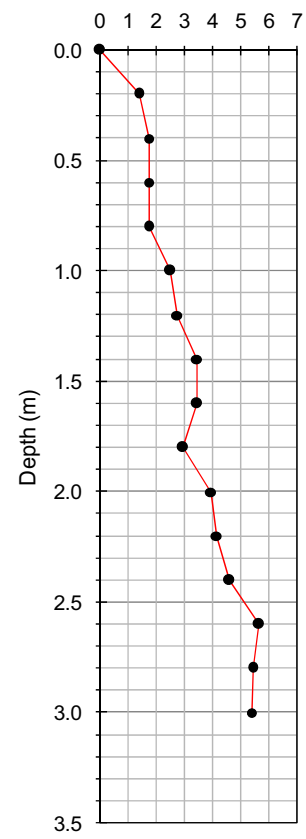

Fig. 12. CPT results for MB2

From Table 6, for the semi-empirical correlation based on the friction ratio in the MB2 area, a soil profile consisting of three soil layers is obtained; the first layer, the type of soil is fine sand, silty to clayey sands. In the second layer, the soil types are sandy clay, silty clays, clays, organic clays. The third layer, soil type, is peat. According to Robertson and Campanella (1983), the soil profile MB2 areas consists of eight soil layers.

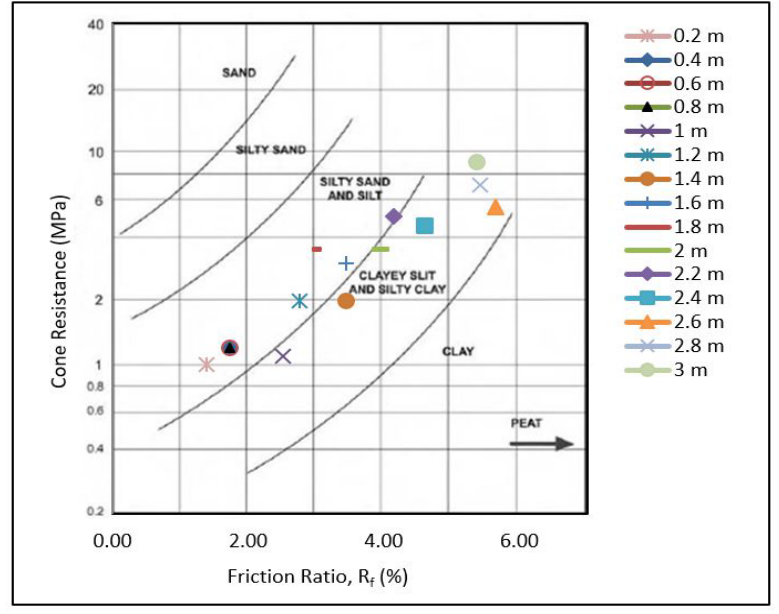

Fig. 13. Plotting CPT data for MB2 (Robertson and Campanella, 1983)

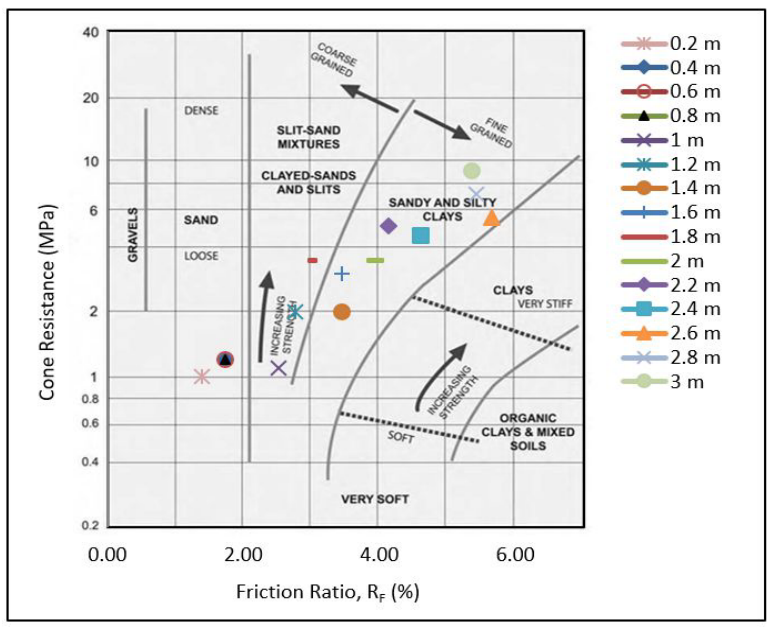

Fig. 14. Plotting CPT data for MB2 (Schertmann, 1978)

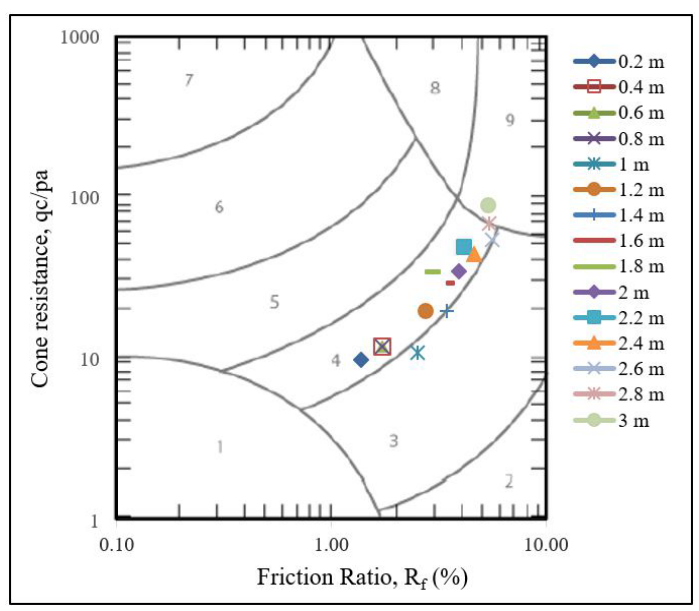

Fig. 15. Plotting CPT data for MB2 (Robertson et al., 1986, updated by Robertson, 2010)

The first, third, fifth, and seventh layers have the same soil type, silty sand, and silt. The second, fourth, sixth, and eighth layers are clayey silt and silty clay. According to Schertmann (1978), the soil type in the MB2 area is the same as the MB1 area, and only the depth is different. 
Robertson et al. (1986), updated by Robertson (2010), obtained a soil type in the MB1 area similar to the MB2 area where the soil profile consists of four soil layers with the depth is different.

Table 6. Soil Behaviour Type (SBT) MB2 area

\begin{tabular}{|c|c|c|c|c|}
\hline $\begin{array}{l}\text { Depth } \\
\text { (m) }\end{array}$ & $\begin{array}{c}\text { Friction } \\
\text { ratios }\end{array}$ & $\begin{array}{c}\text { Robertson and } \\
\text { Campanella } \\
(1983)\end{array}$ & $\begin{array}{c}\text { Schertmann } \\
\text { (1978) }\end{array}$ & $\begin{array}{l}\text { Robertson et al., } \\
\text { 1986, updated by } \\
\text { Robertson, } 2010\end{array}$ \\
\hline 0 & \multirow{5}{*}{$\begin{array}{l}\text { Fine sand, } \\
\text { silty to } \\
\text { clayey } \\
\text { sand }\end{array}$} & \multirow{5}{*}{ Silty sand and silt } & \multirow{5}{*}{ Loose sand } & \multirow{5}{*}{$\begin{array}{l}\text { silt mixtures-clayey } \\
\text { silt to silt clay }\end{array}$} \\
\hline 0.2 & & & & \\
\hline 0.4 & & & & \\
\hline 0.6 & & & & \\
\hline 0.8 & & & & \\
\hline 1 & \multirow{8}{*}{$\begin{array}{c}\text { sandy clay, } \\
\text { silty clays, } \\
\text { clays, } \\
\text { organic } \\
\text { clays }\end{array}$} & $\begin{array}{l}\text { Clayey Silt and } \\
\text { silty clay }\end{array}$ & \multirow{2}{*}{$\begin{array}{l}\text { Clayed-sands } \\
\text { and silts }\end{array}$} & $\begin{array}{l}\text { sand mixtures-silty } \\
\text { sand to sandy silt }\end{array}$ \\
\hline 1.2 & & Silty sand and silt & & \multirow{9}{*}{$\begin{array}{l}\text { silt mixtures-clayey } \\
\text { silt to silt clay }\end{array}$} \\
\hline 1.4 & & $\begin{array}{l}\text { Clayey Silt and } \\
\text { silty clay }\end{array}$ & & \\
\hline 1.6 & & & silty clays & \\
\hline 1.8 & & & $\begin{array}{l}\text { Clayed-sands } \\
\text { and silts }\end{array}$ & \\
\hline 2 & & $\begin{array}{l}\text { Clayey Silt and } \\
\text { silty clay }\end{array}$ & \multirow{6}{*}{$\begin{array}{l}\text { Sandy and } \\
\text { silty clays }\end{array}$} & \\
\hline 2.2 & & Silty sand and silt & & \\
\hline 2.4 & & \multirow{4}{*}{$\begin{array}{l}\text { Clayey Silt and } \\
\text { silty clay }\end{array}$} & & \\
\hline 2.6 & \multirow{3}{*}{ peat } & & & \\
\hline 2.8 & & & & \\
\hline 3 & & & & very stiff fine grainec \\
\hline
\end{tabular}

\section{Conclusions}

Soil classification in the Muaro Baru area based on USCS is poorly graded sand (SP), where the soil is dominated by sand with little silt. Meanwhile, by using several semiempirical correlations, it is found that the number of different soil layers but has almost the same soil type.
The author sincerely thanks the Department of Civil Engineering, Andalas University, for the Finacial Support with contract number 130/UN16.09.D/PL/2021.

\section{References}

1. H. K. S. Begemann, pp. 17-20, (1965).

2. P. K. Robertson, CAN. GEOTECH. J. 27, (1990)

3. A. O. Mohamed and O. A. El Fatih, J. Build. Road Res. 5(August), 37-46 (2003).

4. A. Apriyono, Yanto, P. B. Santoso and Sumiyanto, (EIC 2017) AIP Conference Proc.

5. N. Ecemis and M. Karaman, J. Eng.Geo. pp 48-57, (2014).

6. R. Yuliet, Fauzan, A. Hakam and H. Riani, J. GEOMATE, 17 (59), pp 106-114, (2019)

7. R. Yuliet, A. Hakam, M. Mera, and Fauzan, J. GEOMATE 19 (73), pp.14-19, (2020)

8. R. Yuliet, A. Hakam, M. Mera, and Fauzan, J. GEOMATE 21 (84), pp.41-47 (2021)

9. P. K. Robertson and K. L. Cabal, Gregg drilling and testing, Inc, (2016)

10. B. G. Look, Geotechnical Investigation and Design Tables, Second Edition, CRC Press, pp. 68-70, (2014)

11. Government of Indonesia, Ministry of Public Works and Housing (PWH), Geotechnical Parameter Correlation Set and Foundation, (2019)

12. BSN of Indonesia, Standard test method for Mechanical Cone Penetration Testing of Soils, SNI 2827-2008, Jakarta, Indonesia, (2008)

13. BSN of Indonesia, Standard test method for Particlesize analysis of Soils, SNI 3423-2008, Jakarta, Indonesia, (2008) 